\title{
Periconceptional environment and the developmental origins of disease
}

\author{
Miguel A Velazquez ${ }^{1}$, Tom P Fleming 2 and Adam J Watkins ${ }^{3}$ \\ 1School of Natural and Environmental Sciences, Newcastle University, Newcastle upon Tyne, UK \\ 2Biological Sciences, University of Southampton, Southampton General Hospital, Southampton, UK \\ ${ }^{3}$ Division of Child Health, Obstetrics and Gynaecology, Faculty of Medicine, University of Nottingham, Nottingham, UK \\ Correspondence should be addressed to T P Fleming: tpf@soton.ac.uk
}

This paper is part of a thematic section on 30 Years of the Developmental Endocrinology of Health and Disease. The guest editors for this section were Sean Limesand, Kent Thornburg and Jane Harding.

\begin{abstract}
The concept emerging from Professor David Barker's seminal research on the developmental origins of later-life disease has progressed in many directions since it was first published. One critical question being when during gestation might environment alter the developmental programme with such enduring consequences. Here, we review the growing consensus from clinical and animal research that the period around conception, embracing gamete maturation and early embryogenesis might be the most vulnerable period. We focus on four types of environmental exposure shown to modify periconceptional reproduction and offspring development and health: maternal overnutrition and obesity; maternal undernutrition; paternal diet and health; and assisted reproductive technology. These conditions may act through diverse epigenetic, cellular and physiological mechanisms to alter gene expression and cellular signalling and function in the conceptus affecting offspring growth and metabolism leading to increased risk for cardiometabolic and neurological disease in later life.
\end{abstract}
Key Words
- embryo
- sperm
- parental nutrition
- assisted reproductive technology (ART)
- epigenetics
- cardiometabolic disease

\section{Introduction}

The concept of the early origins of disease associated with in utero environmental factors has been advanced in both clinical and biological directions since the pioneering and groundbreaking epidemiological discoveries by Professor David Barker and his colleagues. Developmental programming of disease has been tested experimentally across global populations providing confirmation of its veracity. In addition, numerous animal models have been generated for insight on mechanisms across physiological, cellular, molecular and epigenetic levels. Much progress on the understanding of the hypothesis, now known as the developmental origins of health and adult disease (DOHaD) concept, has been achieved as evidenced by the varied reviews in this special issue of Journal of Endocrinology dedicated to Professor Barker's seminal work. One critical issue and the subject of our review is the question of when environment may interact with reproduction to initiate a change in the developmental programme leading to DOHaD-related responses and later disease risk.

A growing consensus has emerged that the period around conception is critical in $\mathrm{DOHaD}$. This consensus has come from both animal and human studies, ranging across different environmental exposures from the quality of maternal and paternal nutrition to assisted reproductive technology (ART) (Fig. 1). The stages of gamete maturation, fertilisation and early embryo 


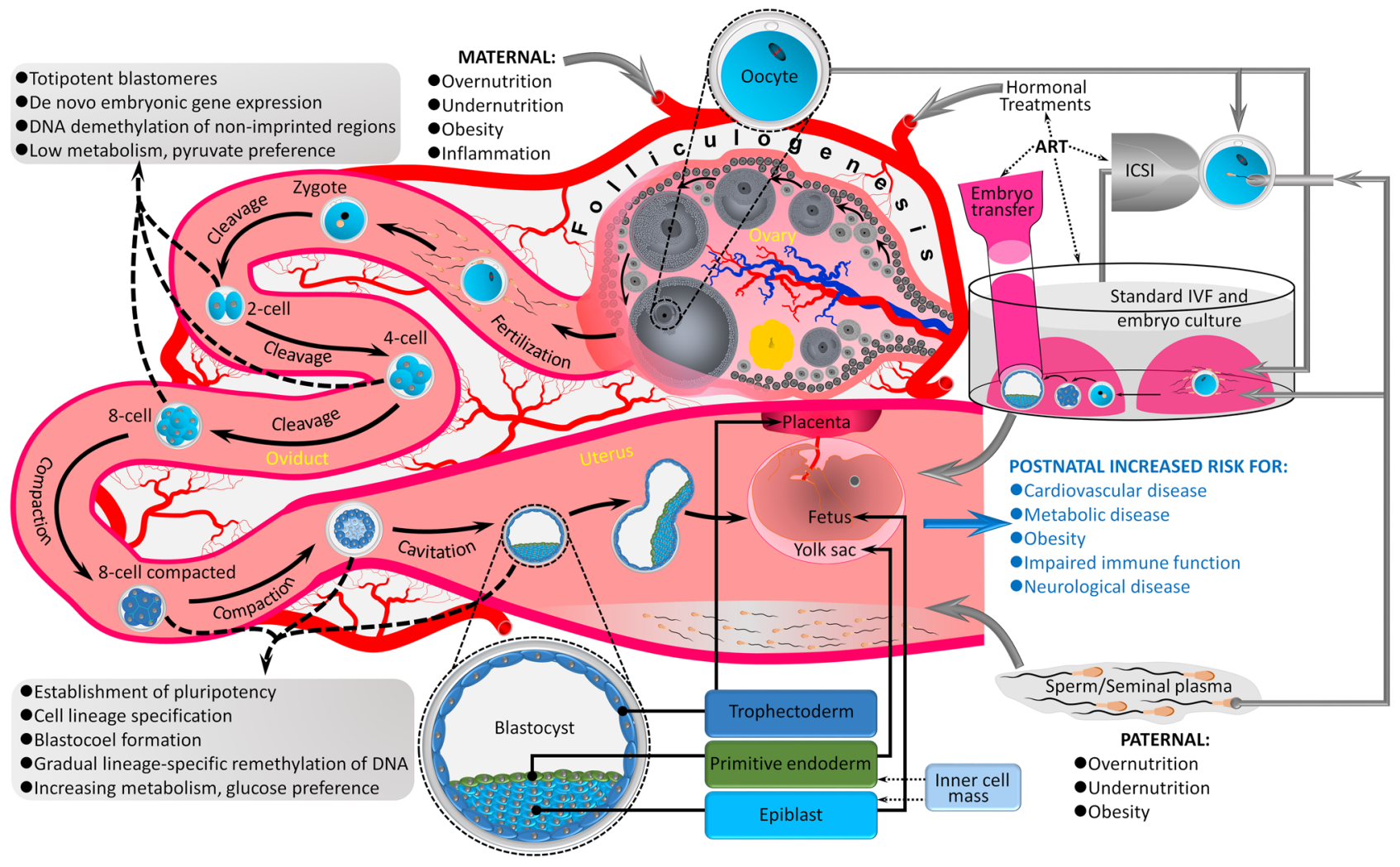

\section{Figure 1}

Summary diagram of the periconceptional period covering gamete maturation and early embryogenesis with key developmental stages and events identified, shown both in vivo and during ART, and with long-term risks for offspring health from adverse exposures listed.

development are collectively known as the periconceptional period. These are characterised by the parental genomes being superseded by the new embryonic genome and the establishment and differentiation of early cell lineages from a pluripotent cellular stock required for the development of new organism (Li et al. 2013, Graham \& Zernicka-Goetz 2016). Such processes involve significant epigenetic, cellular and metabolic activity (Gardner \& Harvey 2015, Lim et al. 2016, White et al. 2016) and, from fertilisation, occur within the confines of the maternal oviduct and uterine lumens, long recognised to facilitate the stepwise progression in gamete and embryo maturation culminating in implantation (Coy et al. 2012, Ghersevich et al. 2015, Matsumoto 2017).

It has become apparent that these periconceptional stages in reproduction are vulnerable to environmental factors that may cause changes, either through perturbation or via adaptive compensatory responses, which may persist beyond the periconceptional period affecting phenotype across the lifespan. We have recently reviewed the vulnerability of periconception in the context of adverse developmental programming with a focus on the consequences of maternal and paternal over- and undernutrition and of ART in human and animal models (Fleming et al. 2018). Maternal or paternal lifestyle factors such as nutritional quality will influence parental physiology in many ways and there is evidence that diet can modify oviduct and uterine transport activities and thereby alter the nutrient composition of luminal compartments and the direct environment experienced by early embryos (Eckert et al. 2012, Jordaens et al. 2017). A similar disturbance to the seminal tubule and sperm microenvironment by the paternal diet has also been reported (Fan et al. 2015). Given the clinical implications raised for next-generation health from a time when many women may not know they are pregnant, these discoveries of environmental susceptibility of periconceptional stages have contributed to the call for considering the preconception health of both partners before pregnancy (Barker et al. 2018, Stephenson et al. 2018).

Here, we summarise the key processes, mechanisms and DOHaD-induced outcomes during the periconceptional window with respect to maternal and paternal nutrition and ART. We focus in particular on new understanding of themes previously presented in our earlier review (Fleming et al. 2018), reflecting the dynamic nature of this subject. 


\section{Maternal overnutrition and obesity}

High maternal body mass index (BMI) and obesity has long been associated with reduced fertility and the occurrence of obesity in children, mediated by raised maternal metabolites such as glucose and insulin promoting increased placental transport of macronutrients and subsequent increase in foetal growth in late gestation (Nicholas et al. 2016, Godfrey et al. 2017, Musial et al. 2017, Nam et al. 2017). The risk of metabolic syndrome in offspring from obese mothers has been substantiated mechanistically in animal models (Samuelsson et al. 2008, Nicholas et al. 2016).

The periconceptional period is critical in the transmission of disease risk from maternal obesity to offspring. Women with high BMI transfer excess metabolites and hormones such as insulin, triglycerides, leptin and lactate from the circulation into ovarian tissue and especially the follicular fluid of maturing follicles (Robker et al. 2009). These metabolites subsequently accumulate within oocytes, affecting their metabolic function and leading to diminished embryo developmental potential after fertilisation (Yang et al. 2012). Interestingly, increased lipid accumulation within human follicular fluid coincides with increased inflammatory mediators that may contribute to the reduced potential of embryos from obese mothers (Gonzalez et al. 2018). Notably, the size of human oocytes is reduced by high maternal BMI and this led to poorer quality embryos with excess triglycerides and diminished glucose consumption (Leary et al. 2015).

Animal models have been used to identify the metabolic defects in oocytes and early embryos caused by maternal overnutrition. Mitochondria become severely affected in their structure and organisation of cristae, in their cellular distribution and rate of biogenesis and critically in their capacity for generating energy in response to maternal overnutrition (Igosheva et al. 2010, Luzzo et al. 2012). These defective mitochondria are more likely to be preserved in embryos since obesity further reduced mitophagy (Boudoures et al. 2017). Moreover, accumulating lipids in oocytes induces endoplasmic reticulum and oxidative stress, impairing developmental potential and increasing aneuploidy (Igosheva et al. 2010, Luzzo et al. 2012, Hou et al. 2016). Maternal diabetes may similarly modulate embryo metabolism, recently investigated in a rabbit model of developmental programming. Here, significant remodelling of several metabolic pathways occurred with a critical role identified for adiponectin in generating lipid accumulation leading to oxidative metabolic stress (Fischer et al. 2017). Further evidence of periconceptional metabolic induction of programming from maternal overnutrition has come from supplementing the diet of obese mice with coenzyme Q10 injection which restored mitochondrial functioning (Boots et al. 2016). Animal in vitro studies have also confirmed that increased levels of fatty acids impair follicular maturation and oocyte potential leading to blastocysts with altered transcription and epigenome profiles (Van Hoeck et al. 2013, Desmet et al. 2016). Such studies also demonstrate fatty acid modulation of oviductal barrier function to influence embryo exposure to nutrient levels (Jordaens et al. 2017). Epigenetic effects have also been demonstrated in the oocytes from obese mouse dams with altered levels of DNA and histone methylation regulators (Hou et al. 2016). Epigenetic change associated with genes regulating metabolic health in offspring has also been shown in an ovine model of maternal overnutrition (Nicholas et al. 2013).

Recent mouse studies have identified a role for PGC7/Stella protein in mediating maternal obesity effects on adverse programming of embryos (Han et al. 2018). Stella is known to regulate the asymmetry in global DNA demethylation between paternal and maternal genomes and protect imprinted genes from demethylation (Nakamura et al. 2007) and becomes depleted in oocytes from obese mothers coinciding with global hypomethylation of the embryonic genome (Han et al. 2018). Notably, restoring Stella expression reverses both the epigenetic status of embryos from obese dams and their developmental defects (Han et al. 2018). A further study has identified reduced expression of TIGAR (TP53-induced glycolysis and apoptosis regulator) in oocytes from obese mothers which may contribute to the increased oxidative stress and meiotic spindle defects in such oocytes (Wang et al. 2018).

These metabolic perturbations induced in oocytes and embryos by maternal overnutrition persist during later development. Mouse foetuses from obese mothers exhibit an altered growth trajectory and give rise to offspring with increased adiposity and metabolic dysfunction such as glucose intolerance (Jungheim et al. 2010). Such physiological responses also coincide with underlying transcriptional and epigenetic changes both in the foetus and placenta (Mahany et al. 2018). Moreover, metabolic dysfunction in offspring from maternal obesity has been shown to persist over three mouse generations, https://joe.bioscientifica.com

https://doi.org/10.1530/JOE-18-0676 (c) 2019 Society for Endocrinology Published by Bioscientifica Ltd.
Printed in Great Britain 
likely reflecting the inheritance of defective maternally derived mitochondria (Saben et al. 2016).

The importance of the periconceptional origin of adverse programming from maternal obesity has been demonstrated using embryo transfer to healthy recipients in mouse and sheep models with the persistence of foetal and postnatal metabolic dysfunction despite a normal uterine environment (Luzzo et al. 2012, Nicholas et al. 2013). A similar periconceptional origin of adverse programming in response to maternal diabetes has been shown by mouse transfer of zygotes to healthy recipients (Wyman et al. 2008). Lastly, consistent with the above, in assisted conception practice, there is some evidence that the maternal BMI of oocyte donors negatively influences reproductive outcomes despite not carrying the pregnancy (Cardozo et al. 2016).

\section{Maternal undernutrition}

The original datasets revealing adverse adult health outcomes derived from in utero experience by David Barker and colleagues implicated maternal undernutrition during pregnancy followed by accelerated catch-up growth postnatally as causative (Barker \& Thornburg 2013). Supporting human evidence linking maternal undernutrition and subsequent adult health risks linked to cardiometabolic and neurological dysfunction have come from well-researched historical famines, particularly the Dutch Hunger Winter of 1944-45 and the Chinese Great Famine over 1959-61 (Roseboom et al. 2011, van den Broek \& Fleischmann 2017, Liu et al. 2018). While such human epidemiological studies are complex and wide ranging, it has been possible to identify early gestation and the periconceptional period as a vulnerable window for adverse programming. Thus, those individuals conceived during the 5-month Dutch famine exhibit poorer cardiometabolic and neurological outcomes in adulthood, including accelerated ageing where the famine experience occurred later in their gestation (Roseboom et al. 2011, Tobi et al. 2014, Franke et al. 2018). A similar increased risk of first trimester exposure has also been shown in the Chinese famine (Wang et al. 2012, Zimmet et al. 2018). In addition, the Dutch famine research has shown that periconceptional exposure leads to epigenetic dysregulation of genes involved in growth and metabolism such as conserved hypomethylation of the imprinted IGF2 gene into adulthood (Tobi et al. 2014).

A further critical human dataset linking maternal periconceptional undernutrition with later adult disease has come from studies on populations in The Gambia. Here, nutritional quality is seasonal and associated with later-life mortality and health risk. The quality of maternal nutrition at conception has been shown to alter the pre-gastrulation epigenome at metastable epialleles, domains characterised by inter-individual variation in DNA methylation, in a manner that persists into childhood and adolescence (Waterland et al. 2010). Such alterations in epigenetic signatures further associate with genomic regions predictive of immune status, obesity risk and tumourigenesis (Silver et al. 2015, Kuhnen et al. 2016). Indeed, metastable epialleles are present in human early embryos and may provide a suitable epigenetic basis for environment to induce persistent phenotypic change during developmental programming (Kessler et al. 2018).

Animal DOHaD studies involving rodents, sheep and cattle have further demonstrated the close association between maternal undernutrition and later-life risk of poor health and again underscore the criticality of the periconceptional period (Sinclair \& Watkins 2013, Hansen et al. 2016, Fleming et al. 2018). From our own work, a maternal low protein diet, effectively $50 \%$ of normal protein recommendation, targeted exclusively to the mouse and rat preimplantation period of embryo development (Emb-LPD) has been shown sufficient to cause adult offspring cardiovascular, metabolic and behavioural dysfunction, especially in female progeny (Kwong et al. 2000, Watkins et al. 2008, Gould et al. 2018). The stepwise mechanistic pathway responsible for Emb-LPD adverse programming has been closely examined. The diet results in reduced concentrations of circulating insulin and amino acids (especially the branched-chain amino acids (BCAAs), leucine, isoleucine and valine) within dams that, through analysis of uterine luminal fluids, also changed the metabolite milieu of the immediate environment of embryos (Eckert et al. 2012). Insulin and BCAAs are potent activators of the mTOR signalling pathway regulating cellular growth (Wang \& Proud 2009) and, as a consequence of dietary-induced reduction in these metabolites, blastocyst mTOR activity is reduced by Emb-LPD (Eckert et al. 2012). This early maternal-embryo interaction is critical since it activates later adverse programming as shown both by an in vitro culture model in medium reduced in insulin and BCAAs (Velazquez et al. 2018) and by embryo transfer of Emb-LPD blastocysts into control, normal-fed, recipients (Watkins et al. 2008).

The subsequent development of the Emb-LPD blastocyst after maternal dietary induction is altered in distinct ways for extra-embryonic (trophectoderm, 
TE; primitive endoderm, PrE) and embryonic (epiblast) cell lineages. These phenotypic modulations impact on the growth trajectory of the foetus which in turn positively correlates with later adult disease risk (Watkins et al. 2008). Both TE and PrE cell lineages, in response to maternal Emb-LPD, undergo cellular changes that collectively are compensatory, likely to augment nutrient delivery to the developing embryo and foetus. These include increased proliferation of the lineages and their capacity for endocytosis of extracellular fluids, thought to increase nutrient supply (Eckert et al. 2012, Sun et al. 2014). The TE also adopts a more invasive migratory phenotype likely to enhance endometrial implantation (Eckert et al. 2012, Watkins et al. 2015). Extra-embryonic adaptations induced by maternal protein restriction persist through pregnancy with evidence of improved nutrient delivery via the chorioallantoic placenta (Coan et al. 2011) and visceral yolk sac (Watkins et al. 2008), the latter coinciding with altered epigenetic regulation of the Gata6 transcription factor that has a central role in PrE differentiation (Sun et al. 2015).

In contrast to extra-embryonic lineages, the somatic tissues of the foetus derived from the epiblast, such as liver and kidney, alter their growth trajectory to match prevailing maternal nutrient availability. This is achieved via the rate of ribosome biogenesis, the fundamental unit of biosynthesis, and specifically ribosomal RNA (rRNA) transcription, which is reduced if the maternal dietary restriction is maintained, but increased beyond control levels, if the dietary challenge is lifted as in Emb-LPD. The manipulation of ribosome biogenesis is regulated epigenetically through the level of DNA methylation at the rDNA gene promoter and coincides with altered expression of the ribosome factor Rrn3, known to link ribosome biogenesis with mTOR nutrient signalling (Denisenko et al. 2016). Thus, the combination of extraembryonic and embryonic lineage adaptations to maternal Emb-LPD from implantation, comprising increased extraembryonic nutrient delivery and increased capacity for foetal biosynthesis, in addition to improved maternal protein diet, all act to promote late foetal overgrowth as a basis for postnatal disease derived from periconceptional environment (Watkins et al. 2008, Fleming et al. 2018).

Recent work has shown that Emb-LPD and sustained LPD treatment throughout pregnancy have a negative influence on neurogenesis. Both treatments lead to a decline in neural stem cells (NSCs) during foetal development through reduced proliferation and increased apoptosis. The loss of NSCs coincides with an altered rate of neural differentiation and a postnatal phenotype of altered cortex thickness and short-term memory loss in both males and females (Gould et al. 2018). These findings extend earlier behavioural outcomes from the mouse Emb-LPD model (Watkins et al. 2008) and confirm periconceptional maternal undernutrition as critical in DOHaD for postnatal health across diverse systems.

\section{Assisted reproductive technologies}

ART refers to any technique that interferes with the normal biological pathways of reproductive-related events and/or structures in order to contribute to the establishment of pregnancy with the final goal of producing healthy offspring. In general, ART manipulates events and/or structures related to ovulation, fertilisation and embryo development (Velazquez 2008). Current estimates from the International Committee Monitoring for Assisted Reproductive Technologies indicate that since the first ART-derived baby in 1978 over 8 million babies have been born through ART worldwide (De Geyter 2018). It should be emphasised that most ART-derived babies appear healthy. But giving the adverse effects associated with ART reported in some human and animal studies (see below), there is an active effort to ensure an efficient and safe application of human ART, including monitoring of the health status of the resultant offspring.

Data from Finland indicated that children up to 4 years of age whose mothers were subjected to ovulation induction with or without intrauterine insemination (IUI) showed an increased risk of cerebral palsy, allergy and asthma, along with longer periods of hospitalisation (Klemetti et al. 2010). A Danish study found that the risk of developing type 1 diabetes during childhood was increased in children conceived through the use of FSH in ovulation induction protocols or in combination with IUI (Kettner et al. 2016). Analysis of the UK data revealed that babies derived from ARTs such as in vitro fertilisation (IVF), intracytoplasmic sperm injection (ICSI), IUI, gamete intra-fallopian transfer and ovulation induction had an increased risk of developing respiratory distress and infection during the first week of life when compared to naturally conceived counterparts (Waynforth 2018). Similarly, a meta-analysis of 45 studies suggested that the risk of developing birth defects can be increased by IVF and ICSI (Hansen et al. 2013), something that has been confirmed in a more recent meta-analysis (Zhao et al. 2018).

Another recent meta-analysis indicated that children conceived by IVF and ICSI showed a lower weight during 
the first 4 years of age, with the difference disappearing afterwards (Bay et al. 2019), indicating an enhanced growth velocity during early development. Rapid growth during early childhood can increase the risk of developing obesity and hypertension later in life (Mihrshahi et al. 2011, Lei et al. 2015). Indeed, IVF children with rapid growth during early childhood (1-3 years of age) showed higher blood pressure levels compared to spontaneously conceived counterparts at 8-18 years of age (Ceelen et al. 2009). Increase in blood pressure in IVF/ICSI-derived children has been detected in several studies (Sakka et al. 2010, Scherrer et al. 2012, Valenzuela-Alcaraz et al. 2013, Meister et al. 2018, Valenzuela-Alcaraz et al. 2018). Reproductive potential seems to be affected as well, especially in males. Young adults conceived through ICSI showed low sperm concentration and motile sperm count compared to men born after spontaneous conception (Belva et al. 2016). Interestingly, the impaired sperm production was not associated with significant changes in reproductive hormones (Belva et al. 2017).

Current evidence seems to indicate that the incidence of certain diseases and some developmental features might not be strongly affected by ART. For instance, the available data indicate that the overall cancer risk does not seem to be increased in ART-derived children, although some studies found a small increased risk for specific types of cancer (Chen \& Heilbronn 2017, Wainstock et al. 2017, Williams et al. 2018). Studies in The Netherlands reported that behavioural and cognitive performance was not affected in ICSI-derived children at 5 years of age when compared to the general Dutch population (Meijerink et al. 2016) and that subfertility rather than ART per se seems to be the underlying cause of impaired cognitive and behavioural development during childhood observed in some ART-derived children (Schendelaar et al. 2016). A recent study from the UK also found that IVF and ICSI do not seem to impair children's early cognitive outcomes up to age 11 years (Barbuscia \& Mills 2017). Similarly, a recent systematic review revealed that ART treatments such as preimplantation genetic diagnosis/screening do not seem to affect cognitive and behavioural development, but they can mildly affect psychomotor development (e.g. dysregulation in posture, muscle tone) of children in their first two years of life. However this subtle psychomotor dysfunction was not detected in follow-up studies in children up to 9 years of age (Natsuaki \& Dimler 2018).

Although these results have been taken as reassuring for ART outcomes affecting offspring mental health (Meijerink et al. 2016), these studies were carried out during early childhood and the truly long-term consequences (i.e. in adulthood) for mental health remain to be determined. Furthermore, there is more uncertainty with some neurodevelopmental disorders. For instance, the occurrence of autism and cerebral palsy in IVF/ICSI-derived children was found to be increased in some (Stromberg et al. 2002, Lehti et al. 2013, Sandin et al. 2013, Kamowski-Shakibai et al. 2015, Schieve et al. 2017, Goldsmith et al. 2018) but not all studies (Kallen et al. 2010, Reid et al. 2010, Fountain et al. 2015, Kissin et al. 2015). Both autism (Fountain et al. 2015) and cerebral palsy (Goldsmith et al. 2018) have been strongly associated with multiple births in ART pregnancies highlighting the need to reduce multiple pregnancies in women undergoing ART (Pinborg 2019).

Most of the above-discussed studies used as comparison group children naturally conceived by fertile couples, which has been suggested not to be the best control group. Instead, naturally conceived children from sub-fertile parents who managed to achieve pregnancy while waiting for ART treatment will be a more appropriate comparison group (Zhao et al. 2018). Although studies using this control group are available, a substantial proportion of human ART studies still have methodological limitations that hamper the ability to provide reliable conclusions (Guo et al. 2017, Liu et al. 2017, Rumbold et al. 2017), to the point that some authors believe their findings (e.g. increased risk of type diabetes due to ovulation induction protocols) are a statistical artefact (Kettner et al. 2016).

Nevertheless, animal models have provided experimental evidence supporting the notion that cardiovascular (Watkins et al. 2007, Rexhaj et al. 2013), metabolic (Chen et al. 2014, Feuer et al. 2014, Cerny et al . 2017), immunological (Karimi et al. 2017), reproductive (Calle et al. 2012) and behavioural (Lopez-Cardona et al. 2015) activity during postnatal development can be affected by ART. These postnatal alterations can be induced by the microenvironment to which embryos are exposed to during in vitro procedures. For example, mice and bovine models have demonstrated that in vitro exposure during the preimplantation period to specific constituents of culture media such as metabolic hormones (e.g. insulin), amino acids, pyruvate, lactate and growth factors can induce alterations in birth weight, body growth rate and cardiovascular function (Banrezes et al. 2011, Kannampuzha-Francis et al. 2015, Velazquez et al. 2018). A similar situation has been found in humans, where the culture medium composition induced changes in birth weight (Kleijkers et al. 2016) and body weight and BMI examined at 9 years of age (Zandstra et al. 2018). Importantly, animal models have revealed that culture 
media modification (e.g. melatonin supplementation) can reverse some of these altered phenotypes (e.g. cardiovascular dysfunction) (Rexhaj et al. 2015).

The current consensus is that the effects of ART on offspring health may have an epigenetic origin (Huntriss et al. 2018). Indeed, a meta-analysis revealed that the incidence of rare imprinting disorders in IVF/ICSI-derived children is higher than in spontaneously conceived children, although the exact underlying epigenetic mechanism is unknown (Lazaraviciute et al. 2014). Nevertheless, compared to methylation levels in somatic and embryonic stem cells, a perturbed methylation of imprinted genes such as SNRPN, KCNQ1OT1 and H19 was found in ART-derived human preimplantation embryos (White et al. 2015). Similarly, changes in DNA methylation were observed in the placenta (Katari et al. 2009, Melamed et al. 2015, Choufani et al. 2018) and cord blood (Katari et al. 2009, Melamed et al. 2015) from ARTderived babies when compared to naturally conceived counterparts. A study comparing natural conception with oocyte donation (i.e. young fertile oocyte donors/ no male infertility) also found differences in placental DNA methylation levels between the groups, suggesting a strong effect of ART and not infertility (Song et al. 2015). Several regulatory regions, metastable epialleles and imprinted genes, including IGF2, were hypomethylated in blood spots from ART-conceived newborns relative to those conceived naturally (Estill et al. 2016). The methylation levels of SNRPN, a paternal imprinted gene, were increased in the buccal cells of 2 year-old children conceived by ICSI, but not by IVF. This hypermethylation is believed to be associated with the greater degree of in vitro manipulation taking place during ICSI (Whitelaw et al. 2014).

These epigenetic changes are partially attributed to the microenvironment in which embryos are cultured, as animal models have revealed that media culture composition can alter DNA methylation profiles in preimplantation embryos (Market-Velker et al. 2010, Canovas et al. 2017). Furthermore, oxygen tension (5\% vs $20 \%$ ) during culture and type of embryo transferred (fresh vs frozen) have the capacity to alter placental methylation levels from ART-conceived babies when compared to natural conception. Importantly, data from pigs indicate that modification of culture media to resemble in vivo composition can induce methylation levels in preimplantation embryos more similar to those produced in vivo (Canovas et al. 2017).

In contrast, DNA methylation was not affected in blood from prepubertal children conceived through IVF
(Oliver et al. 2012). This suggests that ART-induced changes in DNA methylation could be gene- and/or tissue-specific or that postnatal environment masked any subtle changes in DNA methylation induced by ART. The latter emphasises the complexity of epigenetic studies in humans and the need to consider several methodological issues to produce useful epigenetic data (Lazaraviciute $e t$ al. 2014). Also, a critical step in elucidating the long-term effects of ART in human populations is the development of databases for ART surveillance (i.e. health monitoring of ART-derived offspring), something that has been implemented in just a few countries (Pinborg 2019). The first ART-derived baby turned 40 years just recently, hence the long-term repercussions (or lack of) of ART for healthy ageing are far from being elucidated. This highlights the current need for more research throughout the lifespan of ART-derived offspring.

\section{Paternal origin of periconceptional programming}

In contrast to the substantial epidemiological and animal model research linking maternal well-being with offspring programming, our understanding of how a father influences the development and cardiometabolic health of his offspring has been largely overlooked. However, there is now a significant body of data indicating paternal physiological status, lifestyle and environmental exposure to a range of factors not only impact on sperm quality, but also affect the long-term health of his offspring (Fleming et al. 2018). In line with maternal programming studies, animal models have become critical tools for not only defining the underlying paternal mechanisms involved but also identifying central biomarkers of paternal programming ahead of studies using human samples. Studies from humans and animal models have revealed the complexity of both sperm and the seminal plasma, identifying novel processes by which perturbed paternal health at the time of conception affect a dynamic range of reproductive and developmental processes and ultimately, long-term offspring health.

Paternal reproductive health and sperm quality are impaired in response to paternal physiological and lifestyle factors. Mirroring changes in oocyte quality in response to maternal obesity, elevated paternal BMI has been associated with reduced semen volume, sperm number and sperm motility (Chavarro et al. 2010, Ma et al. 2019). Furthermore, sperm from overweight or obese men show higher levels of DNA damage when 
compared to sperm from normal weight males (Kort et al. 2006, Campbell et al. 2015). As obesity is associated with multiple disturbances in metabolic profile including elevated levels of inflammatory markers and metabolic intermediates, the detrimental effects of increasing male BMI on sperm quality is believed to be mediated through increased oxidative damage. Indeed, in both men and rodents, obesity has been shown to result in increased reactive oxygen species generation (Palmer et al. 2011, Tunc et al. 2011) and sperm DNA damage (Duale et al. 2014, Zhao et al. 2014). Furthermore, consumption of high-energy diets has also been associated with reduced sperm morphology, motility and DNA integrity (Agbaje et al. 2007), perturbed testicular metabolism (Rato et al. 2013) and reduced fertility (Bener et al. 2009) in both mice and men. Similar to the effects of paternal overnutrition, deficiency of specific nutrients, or even nutritional imbalance also affect sperm quality. Many macronutrients such as zinc, vitamins and glutathione act as antioxidants to prevent excessive damage from reactive oxygen species. Sperm from infertile men show higher rates of DNA damage which can be reduced following treatment with supplement of selenium and vitamin E (Moslemi \& Tavanbakhsh 2011). In mice, the negative effects of paternal undernutrition on sperm DNA damage can be prevented through dietary supplementation with vitamins and minerals (McPherson et al. 2016).

Poor paternal health not only impacts on sperm quality, but can also affect post-fertilisation development and offspring well-being. In men, some studies have identified associations between obesity and reduced rates of blastocyst development and live birth following IVF (Bakos et al. 2011). Such observations are supported by a recent, large meta-analysis in which the link between paternal obesity and live birth rates after ART cycles was examined in 115,158 patients (Campbell et al. 2015). Here, the authors reported a significant negative impact of increased male BMI on non-viable pregnancy outcomes. In mice, paternal obesity has been reported to increase rates of one-cell block, decrease blastocyst cell number and perturb embryo carbohydrate metabolism (Mitchell et al. 2011, Binder et al. 2012). Our own studies have revealed that a paternal low protein diet (LPD) decreased blastocyst expression of multiple genes involved in the $5^{\prime}$ AMP-activated protein kinase (AMPK) pathway including genes for metabolism, regulation of transcription and protein synthesis (Watkins et al. 2017). Interestingly, similar decreases in several of these AMPK pathway genes were still evident in late gestation foetal liver tissues and associated with increased rates of foetal growth (Watkins et al. 2017). As in studies of poor maternal diet during pregnancy, we observed that the enhanced foetal growth programmed by paternal LPD was associated subsequently with increased adiposity, impaired glucose metabolism, hypotension and vascular dysfunction in adult offspring (Watkins \& Sinclair 2014). Separately, other studies have shown significant changes in foetal (Carone et al. 2010, Lambrot et al. 2013) and postnatal offspring development and metabolic health (Anderson et al. 2006, McPherson et al. 2016, Ryan et al. 2018) in response to paternal diet or food intake in mice. Interestingly, recent studies have demonstrated robust transgenerational effects of chronic paternal stress on offspring well-being and hypothalamic pituitary adrenal axis function (Gapp et al. 2014, Rodgers et al. 2015).

The fact that many paternal programming studies identify consistent transgenerational programming effects (Fullston et al. 2013, Gapp et al. 2014) indicates changes in sperm epigenetic status as one potential mechanism linking paternal well-being with offspring development. Over recent years the epigenetic complexity of mammalian sperm has been revealed. In contrast to the oocyte, sperm contain almost no cytoplasm and the DNA is packaged using protamines rather than histones. Inappropriate protamine packaging of the sperm DNA, or perturbed histone to protamine transition can be indicative of impairments in the fundamental process of spermatogenesis (Sakkas et al. 2002) or damage due to excessive exposure to reactive oxygen species (Sakka et al. 2010). Furthermore, atypical chromosome packaging and localisation within the sperm or perturbed telomerecentromere interactions have been associated with infertility in some men (Zalensky \& Zalenskaya 2007), while sperm chromatin maturation level has been linked with pregnancy establishment rates (de Lamirande et al. 2012). While the majority of the sperm DNA is re-packaged with protamines, specific genomic sequences retain their histone marks. What is interesting is that the location of these retained histones is not random, but specific to important developmental genes (Hammoud et al. 2009) and retrotransposable long and short interspersed nuclear elements in both men and mice (Samans et al. 2014). Furthermore, some of these sperm-specific histones have been shown to be retained within the oocyte and contribute to the zygotic genome (van der Heijden et al. 2008).

In addition to sperm chromatin structure, differential profiles of DNA methylation have also been linked to sperm quality in infertile men (Hammoud et al. 2010). In studies looking at success rates of women undergoing IVF, 
the genome-wide methylation profile of their partner's sperm correlated with embryo quality (Aston et al. 2015) and was indicative of pregnancy failure (Benchaib et al. 2005). In mice, significant changes in sperm DNA methylation profiles have also been identified in response to paternal obesity (Fullston et al. 2013), low protein (Carone et al. 2010) or low folate (Lambrot et al. 2013) diets. Our own studies have showed that feeding male mice a LPD results in global sperm hypomethylation associated with reduced testicular expression of central regulators of DNA methylation and 1-carbon metabolism (Watkins et al. 2018). Interestingly, analysis of the sperm DNA hypomethylation revealed significant reductions at multiple genes involved in calcium signalling which correlated with our earlier reported impairments in cardiovascular function and cardiac calcium signalling gene expression in adult offspring of LPD-fed males (Watkins \& Sinclair 2014). In addition to histone and DNA modifications, sperm has been shown to contain a range of RNA species including mRNA, microRNA, short and long noncoding RNA and small interfering RNAs (Colaco \& Sakkas 2018). The significance of spermderived RNAs for post-fertilisation development has been demonstrated in animal models where the depletion of specific sperm microRNAs results in developmental delay of the zygote (Liu et al. 2012). In addition, injection of tRNA-derived small RNAs from sperm of high-fat dietfed male mice into control zygotes resulted in impaired glucose metabolism and insulin secretion in the resultant offspring (Chen et al. 2016).

Separate to the epigenetic status of the sperm, fathers may also influence the development of their offspring via seminal plasma-specific modulations of the maternal reproductive tract environment (Robertson \& Sharkey 2016). In both mice and women, deposition of seminal plasma within the reproductive tract initiates a significant inflammatory and immunological response culminating in uterine vascular remodelling, the recruitment of leukocytes and the priming of regulatory $\mathrm{T}$ cells (T-regs) and the production of a myriad of cell-signalling molecules such as colony-stimulating factor-2 (CSF2), leukaemia inhibitory factor and interleukin 6 (IL-6) (Schjenken \& Robertson 2014). Interestingly, studies have demonstrated positive associations between a woman's unprotected exposure to her partner's seminal plasma and a reduced risk for her developing preeclampsia during pregnancy (Robillard et al. 1994). In mice, lack of seminal plasma at the time of conception has been shown to impair embryo development, foetal growth and adult offspring cardiometabolic health (Bromfield et al. 2014). Our own studies have shown that offspring growth and metabolic health appear equally compromised in response to either sperm or seminal plasma from male mice fed a LPD (Watkins et al. 2018).

\section{Conclusions}

It is clear from the above four types of exposure during periconceptional reproduction that altered developmental programming may emerge from diverse environments (summarised in Table 1). While here we focus on parental nutrition in vivo and embryo manipulations in vitro, the spectrum of exposures with enduring consequences is undoubtedly broader. For example, periconceptional maternal alcohol consumption prior to embryo implantation in a rat model resulted in abnormal trophoblast placental function, altered expression of epigenetic regulators for DNA methylation in the foetal liver, culminating in postnatal glucose and insulin intolerance and increased risk of offspring obesity (Gardebjer et al. 2015, Kalisch-Smith et al. 2016, Gardebjer et al. 2018). In another example, maternal sickness and systemic inflammation at the time of conception has been shown in a mouse model to alter blastocyst morphogenesis with long-term consequences for adult offspring immune function (Williams et al. 2011). Here, reproductive function and embryo implantation are in part regulated by the activity of maternal immune cells and the balance of pro- and anti-inflammatory cytokines can have significant influence not only on embryo survival but long-term health of offspring (Robertson et al. 2015).

The extent to which periconceptional exposure can associate with adult DOHaD consequences is also influenced by intrinsic processes such as maternal ageing. While it is well established that fertility declines with age, the developmental potential of oocytes with advancing age is also affected. In a recent mouse study, preimplantation embryos from aged vs young mothers, both sired by young males and transferred to young recipients to carry the pregnancy, gave rise to offspring with altered growth and increased cardiometabolic dysfunction (Velazquez et al. 2016). Oocytes from older mothers exhibit mitochondrial dysfunction and perturbed energy homeostasis (Dumesic et al. 2015) which may indicate adverse programming derives from similar processes as occurs following maternal overnutrition, although mechanisms are underexplored.

A consistent feature across the research field of periconceptional programming has been the involvement of epigenetic dysregulation as a means by which effects 
Table 1 Summary of main environmental exposures discussed in the review and their impact during development and health outcomes in later life.

\begin{tabular}{|c|c|c|c|c|}
\hline \multirow{3}{*}{$\begin{array}{l} \\
\text { Impact on gamete } \\
\text { quality and parental } \\
\text { environment }\end{array}$} & \multicolumn{4}{|c|}{ Insult } \\
\hline & Maternal overnutrition & Maternal undernutrition & Paternal nutrition & $\begin{array}{l}\text { Assisted reproductive } \\
\text { technologies (ART) }\end{array}$ \\
\hline & $\begin{array}{l}\text { Excess follicular } \\
\text { metabolite } \\
\text { concentration } \\
\text { Reduction in oocyte } \\
\text { size and embryo } \\
\text { quality } \\
\text { - Increased oocyte lipid } \\
\text { accumulation, ER stress } \\
\text { and mitochondrial } \\
\text { dysfunction } \\
\text { - Perturbed expression } \\
\text { of epigenetic } \\
\text { regulators }\end{array}$ & $\begin{array}{l}\text { - Altered uterine metabolite } \\
\text { concentrations }\end{array}$ & $\begin{array}{ll}\text { - } & \text { Elevated sperm DNA } \\
\text { damage } \\
\text { - } \\
\text { Altered sperm } \\
\text { epigenome } \\
\text { - } \text { Altered sperm RNA } \\
\text { content } \\
\text { - Altered seminal } \\
\text { plasma composition }\end{array}$ & \\
\hline $\begin{array}{l}\text { Impact on embryo } \\
\text { development }\end{array}$ & $\begin{array}{l}\text { Increased oxidative } \\
\text { metabolic stress } \\
\text { Altered profiles of } \\
\text { transcription }\end{array}$ & $\begin{array}{l}\text { - } \quad \text { Reduced blastocyst mTOR } \\
\text { signalling } \\
\text { - Extra-embryonic cellular } \\
\text { adaptations to enhance } \\
\text { nutrient retrieval }\end{array}$ & $\begin{array}{l}\text { - Reduced APMK gene } \\
\text { expression } \\
\text { - Altered } \\
\text { maternal uterine } \\
\text { immunological } \\
\text { environment }\end{array}$ & $\begin{array}{ll}\text { - } & \text { Altered } \\
& \text { epigenetic status }\end{array}$ \\
\hline $\begin{array}{l}\text { Impact on offspring } \\
\text { phenotype and } \\
\text { health }\end{array}$ & $\begin{array}{l}\text { - Increased foetal } \\
\text { growth } \\
\text { - Altered placental } \\
\text { epigenetic status } \\
\text { - Increased offspring } \\
\text { adiposity } \\
\text { - Cardiometabolic } \\
\text { dysfunction }\end{array}$ & $\begin{array}{c}\text { - Altered epigenetic status } \\
\text { - Altered ribosome } \\
\text { biogenesis } \\
\text { - Increased foetal growth } \\
\text { - Increased adiposity } \\
\text { - Cardiometabolic } \\
\text { dysfunction } \\
\text { - Neurodevelopmental } \\
\text { dysfunction } \\
\text { - Perturbed imprinted gene } \\
\text { epigenetic status }\end{array}$ & $\begin{array}{l}\text { Perturbed foetal } \\
\text { growth } \\
\text { - Increased offspring } \\
\text { adiposity } \\
\text { - Cardiometabolic } \\
\text { dysfunction }\end{array}$ & $\begin{array}{ll}\text { - } & \text { Altered birth } \\
\text { weight } \\
\text { - Increased early } \\
\text { life growth } \\
\text { - Poorer } \\
\text { cardiometabolic } \\
\text { health } \\
\text { - } \text { Reduced sperm } \\
\text { counts } \\
\text { - Increased rates } \\
\text { of imprinting } \\
\text { disorders }\end{array}$ \\
\hline
\end{tabular}

on gene expression and cellular phenotype may persist through gestation and later life (Steegers-Theunissen et al. 2013). Manipulation of periconception maternal diet composition to reduce the availability of methyl donors for DNA and histone methylation via one-carbon metabolism has been shown to alter the offspring epigenome with accompanying cardiometabolic disease outcomes (Sinclair et al. 2007). Provision of methyl donors can also reverse adverse programming mediated through the rat maternal LPD model (Lillycrop et al. 2005). Animal oocytes and early embryos are known to express key enzymes in the methionine/folate cycles (Kwong et al. 2010) and a role for mTOR signalling has been identified for sensing the levels of folate available for placental development and foetal growth (Rosario et al. 2017, Gupta \& Jansson 2018). Variability across individuals and ethnic groups in regulatory genes involved in one-carbon metabolism may contribute to the relative susceptibility to adverse programming (Clare et al. 2018). What is clear is that health of both parents in terms of diet and physiological condition is an important factor to establish before conception rather than later in pregnancy to protect the health of the next generation.

\section{Declaration of interest}

The authors declare that there is no conflict of interest that could be perceived as prejudicing the impartiality of this review.

\section{Funding}

We are grateful for research funding from BBSRC (BB/1001840/1; BB/ F007450/1), European Union FP7 (Epihealth, 278418; EpiHealthNet, 317146) and Rosetrees Trust to T P F and funding from the BBSRC (BB/ R003556/1) to A J W.

\section{References}

Agbaje IM, Rogers DA, McVicar CM, McClure N, Atkinson AB, Mallidis C \& Lewis SE 2007 Insulin dependant diabetes mellitus: implications for male reproductive function. Human Reproduction 22 1871-1877. (https://doi.org/10.1093/humrep/dem077) https://joe.bioscientifica.com

https://doi.org/10.1530/JOE-18-0676 (c) 2019 Society for Endocrinology Published by Bioscientifica Ltd. Printed in Great Britain 
Anderson LM, Riffle L, Wilson R, Travlos GS, Lubomirski MS \& Alvord WG 2006 Preconceptional fasting of fathers alters serum glucose in offspring of mice. Nutrition 22 327-331. (https://doi. org/10.1016/j.nut.2005.09.006)

Aston KI, Uren PJ, Jenkins TG, Horsager A, Cairns BR, Smith AD \& Carrell DT 2015 Aberrant sperm DNA methylation predicts male fertility status and embryo quality. Fertility and Sterility $\mathbf{1 0 4} 1388$ e1-1397.e1. (https://doi.org/10.1016/j.fertnstert.2015.08.019)

Bakos HW, Henshaw RC, Mitchell M \& Lane M 2011 Paternal body mass index is associated with decreased blastocyst development and reduced live birth rates following assisted reproductive technology. Fertility and Sterility 95 1700-1704. (https://doi.org/10.1016/j. fertnstert.2010.11.044)

Banrezes B, Sainte-Beuve T, Canon E, Schultz RM, Cancela J \& Ozil JP 2011 Adult body weight is programmed by a redox-regulated and energy-dependent process during the pronuclear stage in mouse. PLoS One 6 e29388. (https://doi.org/10.1371/journal.pone.0029388)

Barbuscia A \& Mills MC 2017 Cognitive development in children up to age 11 years born after ART-a longitudinal cohort study. Human Reproduction 32 1482-1488. (https://doi.org/10.1093/humrep/dex102)

Barker DJ \& Thornburg KL 2013 The obstetric origins of health for a lifetime. Clinical Obstetrics and Gynecology 56 511-519. (https://doi. org/10.1097/GRF.0b013e31829cb9ca)

Barker M, Dombrowski SU, Colbourn T, Fall CHD, Kriznik NM, Lawrence WT, Norris SA, Ngaiza G, Patel D, Skordis-Worrall J, et al. 2018 Intervention strategies to improve nutrition and health behaviours before conception. Lancet 391 1853-1864. (https://doi. org/10.1016/S0140-6736(18)30313-1)

Bay B, Lyngso J, Hohwu L \& Kesmodel US 2019 Childhood growth of singletons conceived following in vitro fertilisation or intracytoplasmic sperm injection: a systematic review and metaanalysis. British Journal of Obstetrics and Gynaecology 126 158-166. (https://doi.org/10.1111/1471-0528.15456)

Belva F, Bonduelle M, Roelants M, Michielsen D, Van Steirteghem A, Verheyen G \& Tournaye H 2016 Semen quality of young adult ICSI offspring: the first results. Human Reproduction 31 2811-2820. (https:// doi.org/10.1093/humrep/dew245)

Belva F, Roelants M, De Schepper J, Van Steirteghem A, Tournaye H \& Bonduelle M 2017 Reproductive hormones of ICSI-conceived young adult men: the first results. Human Reproduction 32 439-446. (https:// doi.org/10.1093/humrep/dew324)

Benchaib M, Braun V, Ressnikof D, Lornage J, Durand P, Niveleau A \& Guerin JF 2005 Influence of global sperm DNA methylation on IVF results. Human Reproduction 20 768-773. (https://doi.org/10.1093/ humrep/deh684)

Bener A, Al-Ansari AA, Zirie M \& Al-Hamaq AO 2009 Is male fertility associated with type 2 diabetes mellitus? International Urology and Nephrology 41 777-784. (https://doi.org/10.1007/s11255-009-9565-6)

Binder NK, Hannan NJ \& Gardner DK 2012 Paternal diet-induced obesity retards early mouse embryo development, mitochondrial activity and pregnancy health. PLoS One 7 e52304. (https://doi.org/10.1371/ journal.pone.0052304)

Boots CE, Boudoures A, Zhang W, Drury A \& Moley KH 2016 Obesityinduced oocyte mitochondrial defects are partially prevented and rescued by supplementation with co-enzyme Q10 in a mouse model. Human Reproduction 31 2090-2097. (https://doi.org/10.1093/humrep/ dew181)

Boudoures AL, Saben J, Drury A, Scheaffer S, Modi Z, Zhang W \& Moley KH 2017 Obesity-exposed oocytes accumulate and transmit damaged mitochondria due to an inability to activate mitophagy. Developmental Biology 426 126-138. (https://doi.org/10.1016/j. ydbio.2017.04.005)

Bromfield JJ, Schjenken JE, Chin PY, Care AS, Jasper MJ \& Robertson SA 2014 Maternal tract factors contribute to paternal seminal fluid impact on metabolic phenotype in offspring. PNAS $1112200-2205$ (https://doi.org/10.1073/pnas.1305609111)
Calle A, Miranda A, Fernandez-Gonzalez R, Pericuesta E, Laguna R \& Gutierrez-Adan A 2012 Male mice produced by in vitro culture have reduced fertility and transmit organomegaly and glucose intolerance to their male offspring. Biology of Reproduction 87 34. (https://doi org/10.1095/biolreprod.112.100743)

Campbell JM, Lane M, Owens JA \& Bakos HW 2015 Paternal obesity negatively affects male fertility and assisted reproduction outcomes: a systematic review and meta-analysis. Reproductive Biomedicine Online 31 593-604. (https://doi.org/10.1016/j.rbmo.2015.07.012)

Canovas S, Ivanova E, Romar R, Garcia-Martinez S, Soriano-Ubeda C, Garcia-Vazquez FA, Saadeh H, Andrews S, Kelsey G \& Coy P 2017 DNA methylation and gene expression changes derived from assisted reproductive technologies can be decreased by reproductive fluids. eLife 6. (https://doi.org/10.7554/eLife.23670)

Cardozo ER, Karmon AE, Gold J, Petrozza JC \& Styer AK 2016 Reproductive outcomes in oocyte donation cycles are associated with donor BMI. Human Reproduction 31 385-392. (https://doi. org/10.1093/humrep/dev298)

Carone BR, Fauquier L, Habib N, Shea JM, Hart CE, Li R, Bock C, Li C, $\mathrm{Gu} \mathrm{H}$, Zamore PD, et al. 2010 Paternally induced transgenerational environmental reprogramming of metabolic gene expression in mammals. Cell 143 1084-1096. (https://doi.org/10.1016/j. cell.2010.12.008

Ceelen M, van Weissenbruch MM, Prein J, Smit JJ, Vermeiden JP, Spreeuwenberg M, van Leeuwen FE \& Delemarre-van de Waal HA 2009 Growth during infancy and early childhood in relation to blood pressure and body fat measures at age 8-18 years of IVF children and spontaneously conceived controls born to subfertile parents. Human Reproduction 24 2788-2795. (https://doi.org/10.1093/ humrep/dep273)

Cerny D, Sartori C, Rimoldi SF, Meister T, Soria R, Bouillet E, Scherrer U \& Rexhaj E 2017 Assisted reproductive technologies predispose to insulin resistance and obesity in male mice challenged With a high-fat diet. Endocrinology 158 1152-1159. (https://doi.org/10.1210/ en.2016-1475)

Chavarro JE, Toth TL, Wright DL, Meeker JD \& Hauser R 2010 Body mass index in relation to semen quality, sperm DNA integrity, and serum reproductive hormone levels among men attending an infertility clinic. Fertility and Sterility 93 2222-2231. (https://doi.org/10.1016/j. fertnstert.2009.01.100)

Chen M \& Heilbronn LK 2017 The health outcomes of human offspring conceived by assisted reproductive technologies (ART). Journal of Developmental Origins of Health and Disease 8 388-402. (https://doi. org/10.1017/S2040174417000228)

Chen M, Wu L, Zhao J, Wu F, Davies MJ, Wittert GA, Norman RJ, Robker RL \& Heilbronn LK 2014 Altered glucose metabolism in mouse and humans conceived by IVF. Diabetes 63 3189-3198. (https://doi. org/10.2337/db14-0103)

Chen Q, Yan M, Cao Z, Li X, Zhang Y, Shi J, Feng GH, Peng H, Zhang X, Zhang Y, et al. 2016 Sperm tsRNAs contribute to intergenerational inheritance of an acquired metabolic disorder. Science 351 397-400. (https://doi.org/10.1126/science.aad7977)

Choufani S, Turinsky AL, Melamed N, Greenblatt E, Brudno M, Bérard A Fraser WD, Weksberg R, Trasler J, Monnier P, et al. 2018 Impact of assisted reproduction, infertility, sex, and paternal factors on the placental DNA methylome. Human Molecular Genetics 28 372-385. (https://doi.org/10.1093/hmg/ddy321)

Clare CE, Brassington AH, Kwong WY \& Sinclair KD 2018 Onecarbon metabolism: linking nutritional biochemistry to epigenetic programming of long-term development. Annual Review of Animal Biosciences [epub]. (https://doi.org/10.1146/annurevanimal-020518-115206)

Coan PM, Vaughan OR, McCarthy J, Mactier C, Burton GJ, Constancia M \& Fowden AL 2011 Dietary composition programmes placental phenotype in mice. Journal of Physiology 589 3659-3670. (https://doi. org/10.1113/jphysiol.2011.208629) https://joe.bioscientifica.com

https://doi.org/10.1530/JOE-18-0676 (c) 2019 Society for Endocrinology Published by Bioscientifica Ltd. Printed in Great Britain 
Colaco S \& Sakkas D 2018 Paternal factors contributing to embryo quality. Journal of Assisted Reproduction and Genetics [epub]. (https:// doi.org/10.1007/s10815-018-1304-4)

Coy P, Garcia-Vazquez FA, Visconti PE \& Aviles M 2012 Roles of the oviduct in mammalian fertilization. Reproduction 144 649-660. (https://doi.org/10.1530/REP-12-0279)

De Geyter D 2018 More than 8 million babies born from IVF since the world's first in 1978. Grimbergen, Belgium: European Society of Human Reproduction and Embryology (ESHRE). (available at: https://www. eshre.eu/ESHRE2018/Media/ESHRE-2018-Press-releases/De-Geyter.aspx)

de Lamirande E, San Gabriel MC \& Zini A 2012 Human sperm chromatin undergoes physiological remodeling during in vitro capacitation and acrosome reaction. Journal of Andrology 33 1025-1035. (https://doi. org/10.2164/jandrol.111.015982)

Denisenko O, Lucas ES, Sun C, Watkins AJ, Mar D, Bomsztyk K \& Fleming TP 2016 Regulation of ribosomal RNA expression across the lifespan is fine-tuned by maternal diet before implantation. Biochimica and Biophysica Acta 1859 906-913. (https://doi.org/10.1016/j. bbagrm.2016.04.001)

Desmet KL, Van Hoeck V, Gagne D, Fournier E, Thakur A, O'Doherty AM, Walsh CP, Sirard MA, Bols PE \& Leroy JL 2016 Exposure of bovine oocytes and embryos to elevated non-esterified fatty acid concentrations: integration of epigenetic and transcriptomic signatures in resultant blastocysts. BMC Genomics 17 1004. (https:// doi.org/10.1186/s12864-016-3366-y)

Duale N, Steffensen IL, Andersen J, Brevik A, Brunborg G \& Lindeman B 2014 Impaired sperm chromatin integrity in obese mice. Andrology 2 234-243. (https://doi.org/10.1111/j.2047-2927.2013.00178.x)

Dumesic DA, Meldrum DR, Katz-Jaffe MG, Krisher RL \& Schoolcraft WB 2015 Oocyte environment: follicular fluid and cumulus cells are critical for oocyte health. Fertility and Sterility 103 303-316. (https:// doi.org/10.1016/j.fertnstert.2014.11.015)

Eckert JJ, Porter R, Watkins AJ, Burt E, Brooks S, Leese HJ, Humpherson PG, Cameron IT \& Fleming TP 2012 Metabolic induction and early responses of mouse blastocyst developmental programming following maternal low protein diet affecting lifelong health. PLoS One 7 e52791. (https://doi.org/10.1371/journal. pone.0052791)

Estill MS, Bolnick JM, Waterland RA, Bolnick AD, Diamond MP \& Krawetz SA 2016 Assisted reproductive technology alters deoxyribonucleic acid methylation profiles in bloodspots of newborn infants. Fertility and Sterility 106 629.e10-639.e10. (https://doi. org/10.1016/j.fertnstert.2016.05.006)

Fan Y, Liu Y, Xue K, Gu G, Fan W, Xu Y \& Ding Z 2015 Diet-induced obesity in male C57BL/6 mice decreases fertility as a consequence of disrupted blood-testis barrier. PLoS One 10 e0120775. (https://doi. org/10.1371/journal.pone.0120775)

Feuer SK, Liu X, Donjacour A, Lin W, Simbulan RK, Giritharan G, Piane LD, Kolahi K, Ameri K, Maltepe E, et al. 2014 Use of a mouse in vitro fertilization model to understand the developmental origins of health and disease hypothesis. Endocrinology 155 1956-1969. (https:// doi.org/10.1210/en.2013-2081)

Fischer B, Schindler M, Mareike Pendzialek S, Gurke J, Haucke E, Grybel KJ, Thieme R \& Santos AN 2017 The long-term effect of the periconception period on the embryo's epigenetic profile and phenotype: the role of maternal disease such as diabetes and how the effect is mediated (example from a rabbit model). Advances in Experimental Medicine and Biology 1014 107-115. (https://doi. org/10.1007/978-3-319-62414-3 6)

Fleming TP, Watkins AJ, Velazquez MA, Mathers JC, Prentice AM, Stephenson J, Barker M, Saffery R, Yajnik CS, Eckert JJ, et al. 2018 Origins of lifetime health around the time of conception: causes and consequences. Lancet 391 1842-1852. (https://doi.org/10.1016/ S0140-6736(18)30312-X

Fountain C, Zhang Y, Kissin DM, Schieve LA, Jamieson DJ, Rice C \& Bearman P 2015 Association between assisted reproductive technology conception and autism in California, 1997-2007. American Journal of Public Health 105 963-971. (https://doi. org/10.2105/AJPH.2014.302383)

Franke K, Gaser C, Roseboom TJ, Schwab M \& de Rooij SR 2018 Premature brain aging in humans exposed to maternal nutrient restriction during early gestation. Neuroimage 173 460-471. (https:// doi.org/10.1016/j.neuroimage.2017.10.047)

Fullston T, Ohlsson Teague EM, Palmer NO, DeBlasio MJ, Mitchell M, Corbett M, Print CG, Owens JA \& Lane M 2013 Paternal obesity initiates metabolic disturbances in two generations of mice with incomplete penetrance to the $\mathrm{F} 2$ generation and alters the transcriptional profile of testis and sperm microRNA content. FASEB Journal 27 4226-4243. (https://doi.org/10.1096/fj.12-224048)

Gapp K, Jawaid A, Sarkies P, Bohacek J, Pelczar P, Prados J, Farinelli L, Miska E \& Mansuy IM 2014 Implication of sperm RNAs in transgenerational inheritance of the effects of early trauma in mice. Nature Neuroscience 17 667-669. (https://doi.org/10.1038/nn.3695)

Gardebjer EM, Anderson ST, Pantaleon M, Wlodek ME \& Moritz KM 2015 Maternal alcohol intake around the time of conception causes glucose intolerance and insulin insensitivity in rat offspring, which is exacerbated by a postnatal high-fat diet. FASEB Journal 29 2690-2701. (https://doi.org/10.1096/fj.14-268979)

Gardebjer EM, Cuffe JSM, Ward LC, Steane S, Anderson ST, Dorey ES, Kalisch-Smith JI, Pantaleon M, Chong S, Yamada L, et al. 2018 Effects of periconceptional maternal alcohol intake and a postnatal high-fat diet on obesity and liver disease in male and female rat offspring. American Journal of Physiology. Endocrinology and Metabolism 315 E694-E704. (https://doi.org/10.1152/ajpendo.00251.2017)

Gardner DK \& Harvey AJ 2015 Blastocyst metabolism. Reproduction, Fertility, and Development 27 638-654. (https://doi.org/10.1071/ RD14421)

Ghersevich S, Massa E \& Zumoffen C 2015 Oviductal secretion and gamete interaction. Reproduction 149 R1-R14. (https://doi. org/10.1530/REP-14-0145)

Godfrey KM, Reynolds RM, Prescott SL, Nyirenda M, Jaddoe VW, Eriksson JG \& Broekman BF 2017 Influence of maternal obesity on the long-term health of offspring. Lancet Diabetes and Endocrinology 5 53-64. (https://doi.org/10.1016/S2213-8587(16)30107-3)

Goldsmith S, McIntyre S, Badawi N \& Hansen M 2018 Cerebral palsy after assisted reproductive technology: a cohort study. Developmental Medicine and Child Neurology 60 73-80. (https://doi.org/10.1111/ dmcn.13577)

Gonzalez MB, Lane M, Knight EJ \& Robker RL 2018 Inflammatory markers in human follicular fluid correlate with lipid levels and body mass index. Journal of Reproductive Immunology 130 25-29. (https:// doi.org/10.1016/j.jri.2018.08.005)

Gould JM, Smith PJ, Airey CJ, Mort EJ, Airey LE, Warricker FDM, Pearson-Farr JE, Weston EC, Gould PJW, Semmence OG, et al. 2018 Mouse maternal protein restriction during preimplantation alone permanently alters brain neuron proportion and adult shortterm memory. PNAS 115 E7398-E7407. (https:/doi.org/10.1073/ pnas.1721876115)

Graham SJ \& Zernicka-Goetz M 2016 The acquisition of cell fate in mouse development: how do cells first become heterogeneous? Current Topics in Developmental Biology 117 671-695. (https://doi.org/10.1016/ bs.ctdb.2015.11.021)

Guo XY, Liu XM, Jin L, Wang TT, Ullah K, Sheng JZ \& Huang HF 2017 Cardiovascular and metabolic profiles of offspring conceived by assisted reproductive technologies: a systematic review and metaanalysis. Fertility and Sterility 107 622.e5-631.e5. (https://doi. org/10.1016/j.fertnstert.2016.12.007)

Gupta MB \& Jansson T 2018 Novel roles of MTOR signaling in regulating fetal growth. Biology of Reproduction [epub]. (https://doi.org/10.1093/ biolre/ioy249)

Hammoud SS, Nix DA, Zhang H, Purwar J, Carrell DT \& Cairns BR 2009 Distinctive chromatin in human sperm packages genes for https://joe.bioscientifica.com

https://doi.org/10.1530/JOE-18-0676 (c) 2019 Society for Endocrinology Published by Bioscientifica Ltd. Printed in Great Britain 
embryo development. Nature $\mathbf{4 6 0} 473-478$. (https://doi.org/10.1038/ nature08162)

Hammoud SS, Purwar J, Pflueger C, Cairns BR \& Carrell DT 2010 Alterations in sperm DNA methylation patterns at imprinted loci in two classes of infertility. Fertility and Sterility 94 1728-1733. (https:// doi.org/10.1016/j.fertnstert.2009.09.010)

Han L, Ren C, Li L, Li X, Ge J, Wang H, Miao YL, Guo X, Moley KH, Shu W, et al. 2018 Embryonic defects induced by maternal obesity in mice derive from Stella insufficiency in oocytes. Nature Genetics $\mathbf{5 0}$ 432-442. (https://doi.org/10.1038/s41588-018-0055-6)

Hansen M, Kurinczuk JJ, Milne E, de Klerk N \& Bower C 2013 Assisted reproductive technology and birth defects: a systematic review and meta-analysis. Human Reproduction Update 19 330-353. (https://doi. org/10.1093/humupd/dmt006)

Hansen PJ, Dobbs KB, Denicol AC \& Siqueira LG 2016 Sex and the preimplantation embryo: implications of sexual dimorphism in the preimplantation period for maternal programming of embryonic development. Cell and Tissue Research 363 237-247. (https://doi. org/10.1007/s00441-015-2287-4)

Hou YJ, Zhu CC, Duan X, Liu HL, Wang Q \& Sun SC 2016 Both diet and gene mutation induced obesity affect oocyte quality in mice. Scientific Reports 6 18858. (https://doi.org/10.1038/srep18858)

Huntriss J, Balen AH, Sinclair KD, Brison DR, Picton HM \& Royal College of Obstetricians Gynaecologists 2018 Epigenetics and reproductive medicine: Scientific Impact Paper No. 57. BJOG 125 e43-e54. (https:// doi.org/10.1111/1471-0528.15240)

Igosheva N, Abramov AY, Poston L, Eckert JJ, Fleming TP, Duchen MR \& McConnell J 2010 Maternal diet-induced obesity alters mitochondrial activity and redox status in mouse oocytes and zygotes. PLoS One $\mathbf{5}$ e10074. (https://doi.org/10.1371/journal.pone.0010074)

Jordaens L, Van Hoeck V, Maillo V, Gutierrez-Adan A, Marei WFA, Vlaeminck B, Thys S, Sturmey RG, Bols PEJ \& Leroy JLMR 2017 Maternal metabolic stress may affect oviduct gatekeeper function. Reproduction 153 759-773. (https://doi.org/10.1530/REP-16-0569)

Jungheim ES, Schoeller EL, Marquard KL, Louden ED, Schaffer JE \& Moley KH 2010 Diet-induced obesity model: abnormal oocytes and persistent growth abnormalities in the offspring. Endocrinology 151 4039-4046. (https://doi.org/10.1210/en.2010-0098)

Kalisch-Smith JI, Outhwaite JE, Simmons DG, Pantaleon M \& Moritz KM 2016 Alcohol exposure impairs trophoblast survival and alters subtype-specific gene expression in vitro. Placenta 46 87-91. (https:// doi.org/10.1016/j.placenta.2016.08.080)

Kallen AJ, Finnstrom OO, Lindam AP, Nilsson EM, Nygren KG \& Olausson PM 2010 Cerebral palsy in children born after in vitro fertilization. Is the risk decreasing? European Journal of Paediatric Neurology 14 526-530. (https://doi.org/10.1016/j.ejpn.2010.03.007)

Kamowski-Shakibai MT, Magaldi N \& Kollia B 2015 Parent-reported use of assisted reproduction technology, infertility, and incidence of autism spectrum disorders. Research in Autism Spectrum Disorders 9 77-95. (https://doi.org/10.1016/j.rasd.2014.10.009)

Kannampuzha-Francis J, Denicol AC, Loureiro B, Kaniyamattam K, Ortega MS \& Hansen PJ 2015 Exposure to colony stimulating factor 2 during preimplantation development increases postnatal growth in cattle. Molecular Reproduction and Development 82 892-897. (https:// doi.org/10.1002/mrd.22533)

Karimi H, Mahdavi P, Fakhari S, Faryabi MR, Esmaeili P, Banafshi O, Mohammadi E, Fathi F \& Mokarizadeh A 2017 Altered helper T cell-mediated immune responses in male mice conceived through in vitro fertilization. Reproductive Toxicology 69 196-203. (https://doi. org/10.1016/j.reprotox.2017.03.005)

Katari S, Turan N, Bibikova M, Erinle O, Chalian R, Foster M, Gaughan JP, Coutifaris C \& Sapienza C 2009 DNA methylation and gene expression differences in children conceived in vitro or in vivo. Human Molecular Genetics 18 3769-3778. (https://doi.org/10.1093/ hmg/ddp319)
Kessler NJ, Waterland RA, Prentice AM \& Silver MJ 2018 Establishment of environmentally sensitive DNA methylation states in the very early human embryo. Science Advances 4 eaat2624. (https://doi. org/10.1126/sciadv.aat2624)

Kettner LO, Matthiesen NB, Ramlau-Hansen CH, Kesmodel US, Bay B \& Henriksen TB 2016 Fertility treatment and childhood type 1 diabetes mellitus: a nationwide cohort study of 565,116 live births. Fertility and Sterility 106 1751-1756. (https://doi.org/10.1016/j. fertnstert.2016.09.009)

Kissin DM, Zhang Y, Boulet SL, Fountain C, Bearman P, Schieve L, Yeargin-Allsopp M \& Jamieson DJ 2015 Association of assisted reproductive technology (ART) treatment and parental infertility diagnosis with autism in ART-conceived children. Human Reproduction 30 454-465. (https://doi.org/10.1093/humrep/deu338)

Kleijkers SHM, Mantikou E, Slappendel E, Consten D, van EchtenArends J, Wetzels AM, van Wely M, Smits LJM, van Montfoort APA, Repping S, et al. 2016 Influence of embryo culture medium (G5 and HTF) on pregnancy and perinatal outcome after IVF: a multicenter RCT. Human Reproduction 31 2219-2230. (https://doi.org/10.1093/ humrep/dew156)

Klemetti R, Sevon T, Gissler M \& Hemminki E 2010 Health of children born after ovulation induction. Fertility and Sterility 93 1157-1168. (https://doi.org/10.1016/j.fertnstert.2008.12.025)

Kort HI, Massey JB, Elsner CW, Mitchell-Leef D, Shapiro DB, Witt MA $\&$ Roudebush WE 2006 Impact of body mass index values on sperm quantity and quality. Journal of Andrology 27 450-452. (https://doi. org $/ 10.2164 /$ jandrol.05124)

Kuhnen P, Handke D, Waterland RA, Hennig BJ, Silver M, Fulford AJ, Dominguez-Salas P, Moore SE, Prentice AM, Spranger J, et al. 2016 Interindividual variation in DNA methylation at a putative POMC metastable epiallele is associated with obesity. Cell Metabolism $\mathbf{2 4}$ 502-509. (https://doi.org/10.1016/j.cmet.2016.08.001)

Kwong WY, Wild AE, Roberts P, Willis AC \& Fleming TP 2000 Maternal undernutrition during the preimplantation period of rat development causes blastocyst abnormalities and programming of postnatal hypertension. Development 127 4195-4202.

Kwong WY, Adamiak SJ, Gwynn A, Singh R \& Sinclair KD 2010 Endogenous folates and single-carbon metabolism in the ovarian follicle, oocyte and pre-implantation embryo. Reproduction 139 705-715. (https://doi.org/10.1530/REP-09-0517)

Lambrot R, Xu C, Saint-Phar S, Chountalos G, Cohen T, Paquet M, Suderman M, Hallett M \& Kimmins S 2013 Low paternal dietary folate alters the mouse sperm epigenome and is associated with negative pregnancy outcomes. Nature Communications 42889. (https://doi.org/10.1038/ncomms3889)

Lazaraviciute G, Kauser M, Bhattacharya S, Haggarty P \& Bhattacharya S 2014 A systematic review and meta-analysis of DNA methylation levels and imprinting disorders in children conceived by IVF/ICSI compared with children conceived spontaneously. Human Reproduction Update 20 840-852. (https://doi.org/10.1093/humupd/dmu033)

Leary C, Leese HJ \& Sturmey RG 2015 Human embryos from overweight and obese women display phenotypic and metabolic abnormalities. Human Reproduction 30 122-132. (https://doi.org/10.1093/humrep/ deu276)

Lehti V, Brown AS, Gissler M, Rihko M, Suominen A \& Sourander A 2013 Autism spectrum disorders in IVF children: a national case-control study in Finland. Human Reproduction 28 812-818. (https://doi. org/10.1093/humrep/des430)

Lei X, Chen Y, Ye J, Ouyang F, Jiang F \& Zhang J 2015 The optimal postnatal growth trajectory for term small for gestational age babies: a prospective cohort study. Journal of Pediatrics 166 54-58. (https://doi. org/10.1016/j.jpeds.2014.09.025)

Li L, Lu X \& Dean J 2013 The maternal to zygotic transition in mammals. Molecular Aspects of Medicine 34 919-938. (https://doi.org/10.1016/j. mam.2013.01.003) https://joe.bioscientifica.com

https://doi.org/10.1530/JOE-18-0676
(C) 2019 Society for Endocrinology Published by Bioscientifica Ltd. Printed in Great Britain 
Lillycrop KA, Phillips ES, Jackson AA, Hanson MA \& Burdge GC 2005 Dietary protein restriction of pregnant rats induces and folic acid supplementation prevents epigenetic modification of hepatic gene expression in the offspring. Journal of Nutrition 135 1382-1386. (https://doi.org/10.1093/jn/135.6.1382)

Lim CY, Knowles BB, Solter D \& Messerschmidt DM 2016 Epigenetic control of early mouse development. Current Topics in Developmental Biology 120 311-360. (https://doi.org/10.1016/bs.ctdb.2016.05.002)

Liu W-M, Pang RTK, Chiu PCN, Wong BPC, Lao K, Lee K-F \& Yeung WSB 2012 Sperm-borne microRNA-34c is required for the first cleavage division in mouse. PNAS 109 490-494. (https://doi.org/10.1073/ pnas.1110368109)

Liu L, Gao J, He X, Cai Y, Wang L \& Fan X 2017 Association between assisted reproductive technology and the risk of autism spectrum disorders in the offspring: a meta-analysis. Scientific Reports 746207 (https://doi.org/10.1038/srep46207)

Liu L, Wang W, Sun J \& Pang Z 2018 Association of famine exposure during early life with the risk of type 2 diabetes in adulthood: a meta-analysis. European Journal of Nutrition 57 741-749. (https://doi. org/10.1007/s00394-016-1363-1)

Lopez-Cardona AP, Fernandez-Gonzalez R, Perez-Crespo M, Alen F, de Fonseca FR, Orio L \& Gutierrez-Adan A 2015 Effects of synchronous and asynchronous embryo transfer on postnatal development, adult health, and behavior in mice. Biology of Reproduction 93 85. (https:// doi.org/10.1095/biolreprod.115.130385)

Luzzo KM, Wang Q, Purcell SH, Chi M, Jimenez PT, Grindler N, Schedl T \& Moley KH 2012 High fat diet induced developmental defects in the mouse: oocyte meiotic aneuploidy and fetal growth retardation/ brain defects. PLoS One 7 e49217. (https://doi.org/10.1371/journal. pone.0049217)

Ma J, Wu L, Zhou Y, Zhang H, Xiong C, Peng Z, Bao W, Meng T \& Liu Y 2019 Association between BMI and semen quality: an observational study of 3966 sperm donors. Human Reproduction 34 155-162. (https://doi.org/10.1093/humrep/dey328)

Mahany EB, Han X, Borges BC, da Silveira Cruz-Machado S, Allen SJ, Garcia-Galiano D, Hoenerhoff MJ, Bellefontaine NH \& Elias CF 2018 Obesity and high-fat diet induce distinct changes in placental gene expression and pregnancy outcome. Endocrinology 159 1718-1733. (https://doi.org/10.1210/en.2017-03053)

Market-Velker BA, Fernandes AD \& Mann MR 2010 Side-by-side comparison of five commercial media systems in a mouse model: suboptimal in vitro culture interferes with imprint maintenance. Biology of Reproduction 83 938-950. (https://doi.org/10.1095/ biolreprod.110.085480)

Matsumoto H 2017 Molecular and cellular events during blastocyst implantation in the receptive uterus: clues from mouse models. Journal of Reproduction and Development 63 445-454. (https://doi. org/10.1262/jrd.2017-047)

McPherson NO, Fullston T, Kang WX, Sandeman LY, Corbett MA, Owens JA \& Lane M 2016 Paternal under-nutrition programs metabolic syndrome in offspring which can be reversed by antioxidant/vitamin food fortification in fathers. Scientific Reports 6 27010. (https://doi.org/10.1038/srep27010)

Meijerink AM, Ramos L, Janssen AJ, Maas-van Schaaijk NM, Meissner A, Repping S, Mochtar MH, Braat DD \& Fleischer K 2016 Behavioral, cognitive, and motor performance and physical development of five-year-old children who were born after intracytoplasmic sperm injection with the use of testicular sperm. Fertility and Sterility 106 1673.e5-1682.e5. (https://doi.org/10.1016/j.fertnstert.2016.09.011)

Meister TA, Rimoldi SF, Soria R, von Arx R, Messerli FH, Sartori C, Scherrer U \& Rexhaj E 2018 Association of assisted reproductive technologies With arterial hypertension During adolescence. Journal of the American College of Cardiology 72 1267-1274. (https://doi. org/10.1016/j.jacc.2018.06.060)

Melamed N, Choufani S, Wilkins-Haug LE, Koren G \& Weksberg R 2015 Comparison of genome-wide and gene-specific DNA methylation between ART and naturally conceived pregnancies. Epigenetics $\mathbf{1 0}$ 474-483. (https://doi.org/10.4161/15592294.2014.988041)

Mihrshahi S, Battistutta D, Magarey A \& Daniels LA 2011 Determinants of rapid weight gain during infancy: baseline results from the NOURISH randomised controlled trial. BMC Pediatrics 11 99. (https:// doi.org/10.1186/1471-2431-11-99)

Mitchell M, Bakos HW \& Lane M 2011 Paternal diet-induced obesity impairs embryo development and implantation in the mouse. Fertility and Sterility 95 1349-1353. (https://doi.org/10.1016/j. fertnstert.2010.09.038)

Moslemi MK \& Tavanbakhsh S 2011 Selenium-vitamin E supplementation in infertile men: effects on semen parameters and pregnancy rate. International Journal of General Medicine 4 99-104. (https://doi.org/10.2147/IJGM.S16275)

Musial B, Vaughan OR, Fernandez-Twinn DS, Voshol P, Ozanne SE, Fowden AL \& Sferruzzi-Perri AN 2017 A Western-style obesogenic diet alters maternal metabolic physiology with consequences for fetal nutrient acquisition in mice. Journal of Physiology 595 4875-4892. (https://doi.org/10.1113/JP273684)

Nakamura T, Arai Y, Umehara H, Masuhara M, Kimura T, Taniguchi H, Sekimoto T, Ikawa M, Yoneda Y, Okabe M, et al. 2007 PGC7/Stella protects against DNA demethylation in early embryogenesis. Nature Cell Biology 9 64-71. (https://doi.org/10.1038/ncb1519)

Nam J, Greenwald E, Jack-Roberts C, Ajeeb TT, Malysheva OV, Caudill MA, Axen K, Saxena A, Semernina E, Nanobashvili K, et al. 2017 Choline prevents fetal overgrowth and normalizes placental fatty acid and glucose metabolism in a mouse model of maternal obesity. Journal of Nutritional Biochemistry 49 80-88. (https://doi. org/10.1016/j.jnutbio.2017.08.004)

Natsuaki MN \& Dimler LM 2018 Pregnancy and child developmental outcomes after preimplantation genetic screening: a meta-analytic and systematic review. World Journal of Pediatrics 14 555-569. (https:// doi.org/10.1007/s12519-018-0172-4)

Nicholas LM, Rattanatray L, MacLaughlin SM, Ozanne SE, Kleemann DO, Walker SK, Morrison JL, Zhang S, Muhlhausler BS, MartinGronert MS, et al. 2013 Differential effects of maternal obesity and weight loss in the periconceptional period on the epigenetic regulation of hepatic insulin-signaling pathways in the offspring. FASEB Journal 27 3786-3796. (https://doi.org/10.1096/fj.13-227918)

Nicholas LM, Morrison JL, Rattanatray L, Zhang S, Ozanne SE \& McMillen IC 2016 The early origins of obesity and insulin resistance: timing, programming and mechanisms. International Journal of Obesity 40 229-238. (https://doi.org/10.1038/ijo.2015.178)

Oliver VF, Miles HL, Cutfield WS, Hofman PL, Ludgate JL \& Morison IM 2012 Defects in imprinting and genome-wide DNA methylation are not common in the in vitro fertilization population. Fertility and Sterility 97 147.e7-153.e7. (https://doi.org/10.1016/j. fertnstert.2011.10.027)

Palmer NO, Fullston T, Mitchell M, Setchell BP \& Lane M 2011 SIRT6 in mouse spermatogenesis is modulated by diet-induced obesity. Reproduction, Fertility, and Development 23 929-939. (https://doi. org/10.1071/RD10326)

Pinborg A 2019 Short and long-term outcomes in children born after assisted reproductive technologies (ART). BJOG 126 145-148. (https:// doi.org/10.1111/1471-0528.15437)

Rato L, Alves MG, Dias TR, Lopes G, Cavaco JE, Socorro S \& Oliveira PF 2013 High-energy diets may induce a pre-diabetic state altering testicular glycolytic metabolic profile and male reproductive parameters. Andrology 1 495-504. (https://doi.org/10.1111/j.20472927.2013.00071.x)

Reid SM, Jaques AM, Susanto C, Breheny S, Reddihough DS \& Halliday J 2010 Cerebral palsy and assisted reproductive technologies: a case-control study. Developmental Medicine and Child Neurology 52 e161-e166. (https://doi.org/10.1111/j.1469-8749.2009.03556.x)

Rexhaj E, Paoloni-Giacobino A, Rimoldi SF, Fuster DG, Anderegg M, Somm E, Bouillet E, Allemann Y, Sartori C \& Scherrer U 2013 Mice 
generated by in vitro fertilization exhibit vascular dysfunction and shortened life span. Journal of Clinical Investigation 123 5052-5060. (https://doi.org/10.1172/JCI68943)

Rexhaj EPireva A, Paoloni-Giacobino A, Allemann Y, Cerny D, Dessen P, Sartori C, Scherrer U, , \& Rimoldi SF 2015 Prevention of vascular dysfunction and arterial hypertension in mice generated by assisted reproductive technologies by addition of melatonin to culture media. American Journal of Physiology. Heart and Circulatory Physiology 309 H1151-H1156. (https://doi.org/10.1152/ajpheart.00621.2014)

Robertson SA \& Sharkey DJ 2016 Seminal fluid and fertility in women. Fertility and Sterility 106 511-519. (https://doi.org/10.1016/j. fertnstert.2016.07.1101)

Robertson SA, Chin PY, Schjenken JE \& Thompson JG 2015 Female tract cytokines and developmental programming in embryos. Advances in Experimental Medicine and Biology 843 173-213. (https://doi. org/10.1007/978-1-4939-2480-6_7)

Robillard PY, Hulsey TC, Perianin J, Janky E, Miri EH \& Papiernik E 1994 Association of pregnancy-induced hypertension with duration of sexual cohabitation before conception. Lancet 344 973-975. (https:// doi.org/10.1016/S0140-6736(94)91638-1)

Robker RL, Akison LK, Bennett BD, Thrupp PN, Chura LR, Russell DL, Lane M \& Norman RJ 2009 Obese women exhibit differences in ovarian metabolites, hormones, and gene expression compared with moderate-weight women. Journal of Clinical Endocrinology and Metabolism 94 1533-1540. (https://doi.org/10.1210/jc.2008-2648)

Rodgers AB, Morgan CP, Leu NA \& Bale TL 2015 Transgenerational epigenetic programming via sperm microRNA recapitulates effects of paternal stress. PNAS 112 13699-13704. (https://doi.org/10.1073/ pnas.1508347112)

Rosario FJ, Powell TL \& Jansson T 2017 mTOR folate sensing links folate availability to trophoblast cell function. Journal of Physiology $\mathbf{5 9 5}$ 4189-4206. (https://doi.org/10.1113/JP272424)

Roseboom TJ, Painter RC, van Abeelen AF, Veenendaal MV \& de Rooij SR 2011 Hungry in the womb: what are the consequences? Lessons from the Dutch famine. Maturitas 70 141-145. (https://doi.org/10.1016/j. maturitas.2011.06.017)

Rumbold AR, Moore VM, Whitrow MJ, Oswald TK, Moran LJ, Fernandez RC, Barnhart KT \& Davies MJ 2017 The impact of specific fertility treatments on cognitive development in childhood and adolescence: a systematic review. Human Reproduction 32 1489-1507. (https://doi.org/10.1093/humrep/dex085)

Ryan DP, Henzel KS, Pearson BL, Siwek ME, Papazoglou A, Guo L, Paesler K, Yu M, Muller R, Xie K, et al. 2018 A paternal methyl donor-rich diet altered cognitive and neural functions in offspring mice. Molecular Psychiatry 23 1345-1355. (https://doi.org/10.1038/ mp.2017.53)

Saben JL, Boudoures AL, Asghar Z, Thompson A, Drury A, Zhang W, Chi M, Cusumano A, Scheaffer S \& Moley KH 2016 Maternal metabolic syndrome programs mitochondrial dysfunction via germline changes across three generations. Cell Reports 16 1-8. (https://doi.org/10.1016/j.celrep.2016.05.065)

Sakka SD, Loutradis D, Kanaka-Gantenbein C, Margeli A, Papastamataki M, Papassotiriou I \& Chrousos GP 2010 Absence of insulin resistance and low-grade inflammation despite early metabolic syndrome manifestations in children born after in vitro fertilization. Fertility and Sterility 94 1693-1699. (https://doi.org/10.1016/j. fertnstert.2009.09.049)

Sakkas D, Moffatt O, Manicardi GC, Mariethoz E, Tarozzi N \& Bizzaro D 2002 Nature of DNA damage in ejaculated human spermatozoa and the possible involvement of apoptosis. Biology of Reproduction $\mathbf{6 6}$ 1061-1067. (https://doi.org/10.1095/biolreprod66.4.1061)

Samans B, Yang Y, Krebs S, Sarode GV, Blum H, Reichenbach M, Wolf E, Steger K, Dansranjavin T \& Schagdarsurengin U 2014 Uniformity of nucleosome preservation pattern in Mammalian sperm and its connection to repetitive DNA elements. Developmental Cell 30 23-35. (https://doi.org/10.1016/j.devcel.2014.05.023)
Samuelsson AM, Matthews PA, Argenton M, Christie MR, McConnell JM, Jansen EH, Piersma AH, Ozanne SE, Twinn DF, Remacle C, et al. 2008 Diet-induced obesity in female mice leads to offspring hyperphagia, adiposity, hypertension, and insulin resistance: a novel murine model of developmental programming. Hypertension 51 383-392. (https:// doi.org/10.1161/HYPERTENSIONAHA.107.101477)

Sandin S, Nygren KG, Iliadou A, Hultman CM \& Reichenberg A 2013 Autism and mental retardation among offspring born after in vitro fertilization. JAMA 310 75-84. (https://doi.org/10.1001/ jama.2013.7222)

Schendelaar P, La Bastide-Van Gemert S, Heineman MJ, Middelburg KJ Seggers J, Van den Heuvel ER \& Hadders-Algra M 2016 Subfertility factors rather than assisted conception factors affect cognitive and behavioural development of 4 -year-old singletons. Reproductive Biomedicine Online 33 752-762. (https://doi.org/10.1016/j. rbmo.2016.08.021)

Scherrer U, Rimoldi SF, Rexhaj E, Stuber T, Duplain H, Garcin S, de Marchi SF, Nicod P, Germond M, Allemann Y, et al. 2012 Systemic and pulmonary vascular dysfunction in children conceived by assisted reproductive technologies. Circulation 125 1890-1896. (https://doi. org/10.1161/CIRCULATIONAHA.111.071183)

Schieve LA, Drews-Botsch C, Harris S, Newschaffer C, Daniels J, DiGuiseppi C, Croen LA \& Windham GC 2017 Maternal and paternal infertility disorders and treatments and autism spectrum disorder: findings from the Study to Explore Early Development. Journal of Autism and Developmental Disorders 47 3994-4005. (https://doi. org/10.1007/s10803-017-3283-1)

Schjenken JE \& Robertson SA 2014 Seminal fluid and immune adaptation for pregnancy - comparative biology in mammalian species. Reproduction in Domestic Animals 49 (Supplement 3) 27-36. (https:// doi.org/10.1111/rda.12383)

Silver MJ, Kessler NJ, Hennig BJ, Dominguez-Salas P, Laritsky E, Baker MS, Coarfa C, Hernandez-Vargas H, Castelino JM, Routledge MN, et al. 2015 Independent genomewide screens identify the tumor suppressor VTRNA2-1 as a human epiallele responsive to periconceptional environment. Genome Biology 16 118. (https://doi.org/10.1186/ s13059-015-0660-y)

Sinclair KD \& Watkins AJ 2013 Parental diet, pregnancy outcomes and offspring health: metabolic determinants in developing oocytes and embryos. Reproduction, Fertility, and Development 26 99-114. (https:// doi.org/10.1071/RD13290)

Sinclair KD, Allegrucci C, Singh R, Gardner DS, Sebastian S, Bispham J, Thurston A, Huntley JF, Rees WD, Maloney CA, et al. 2007 DNA methylation, insulin resistance, and blood pressure in offspring determined by maternal periconceptional B vitamin and methionine status. PNAS 104 19351-19356. (https://doi.org/10.1073/ pnas.0707258104)

Song S, Ghosh J, Mainigi M, Turan N, Weinerman R, Truongcao M, Coutifaris C \& Sapienza C 2015 DNA methylation differences between in vitro- and in vivo-conceived children are associated with ART procedures rather than infertility. Clinical Epigenetics 7 41-41. (https://doi.org/10.1186/s13148-015-0071-7)

Steegers-Theunissen RP, Twigt J, Pestinger V \& Sinclair KD 2013 The periconceptional period, reproduction and long-term health of offspring: the importance of one-carbon metabolism. Human Reproduction Update 19 640-655. (https://doi.org/10.1093/humupd/ dmt041)

Stephenson J, Heslehurst N, Hall J, Schoenaker DAJM, Hutchinson J, Cade JE, Poston L, Barrett G, Crozier SR, Barker M, et al. 2018 Before the beginning: nutrition and lifestyle in the preconception period and its importance for future health. Lancet 391 1830-1841. (https:// doi.org/10.1016/S0140-6736(18)30311-8)

Stromberg B, Dahlquist G, Ericson A, Finnstrom O, Koster M \& Stjernqvist K 2002 Neurological sequelae in children born after in-vitro fertilisation: a population-based study. Lancet 359 461-465. (https://doi.org/10.1016/S0140-6736(02)07674-2) https://joe.bioscientifica.com

https://doi.org/10.1530/JOE-18-0676 (c) 2019 Society for Endocrinology Published by Bioscientifica Ltd. Printed in Great Britain 
Sun C, Velazquez MA, Marfy-Smith S, Sheth B, Cox A, Johnston DA, Smyth N \& Fleming TP 2014 Mouse early extra-embryonic lineages activate compensatory endocytosis in response to poor maternal nutrition. Development 141 1140-1150. (https://doi.org/10.1242/ dev.103952)

Sun C, Denisenko O, Sheth B, Cox A, Lucas ES, Smyth NR \& Fleming TP 2015 Epigenetic regulation of histone modifications and Gata6 gene expression induced by maternal diet in mouse embryoid bodies in a model of developmental programming. BMC Developmental Biology 15 3. (https://doi.org/10.1186/s12861-015-0053-1)

Tobi EW, Goeman JJ, Monajemi R, Gu H, Putter H, Zhang Y, Slieker RC, Stok AP, Thijssen PE, Muller F, et al. 2014 DNA methylation signatures link prenatal famine exposure to growth and metabolism. Nature Communications 5 5592. (https://doi.org/10.1038/ncomms6592)

Tunc O, Bakos HW \& Tremellen K 2011 Impact of body mass index on seminal oxidative stress. Andrologia 43 121-128. (https://doi. $\operatorname{org} / 10.1111 / \mathrm{j} .1439-0272.2009 .01032 . x)$

Valenzuela-Alcaraz B, Crispi F, Bijnens B, Cruz-Lemini M, Creus M, Sitges M, Bartrons J, Civico S, Balasch J \& Gratacos E 2013 Assisted reproductive technologies are associated with cardiovascular remodeling in utero that persists postnatally. Circulation 128 1442-1450. (https://doi.org/10.1161/CIRCULATIONAHA.113.002428)

Valenzuela-Alcaraz B, Serafini A, Sepulveda-Martinez A, Casals G, Rodriguez-Lopez M, Garcia-Otero L, Cruz-Lemini M, Bijnens B, Sitges M, Balasch J, et al. 2018 Postnatal persistence of fetal cardiovascular remodelling associated with assisted reproductive technologies: a cohort study. BJOG 126 291-298. (https://doi. org/10.1111/1471-0528.15246)

van den Broek T \& Fleischmann M 2017 Prenatal famine exposure and mental health in later midlife. Aging and Mental Health 1-5. (https:// doi.org/10.1080/13607863.2017.1402293)

van der Heijden GW, Ramos L, Baart EB, van den Berg IM, Derijck AA, van der Vlag J, Martini E \& de Boer P 2008 Sperm-derived histones contribute to zygotic chromatin in humans. BMC Developmental Biology 8 34. (https://doi.org/10.1186/1471-213X-8-34)

Van Hoeck V, Leroy JL, Arias Alvarez M, Rizos D, Gutierrez-Adan A, Schnorbusch K, Bols PE, Leese HJ \& Sturmey RG 2013 Oocyte developmental failure in response to elevated nonesterified fatty acid concentrations: mechanistic insights. Reproduction 145 33-44. (https://doi.org/10.1530/REP-12-0174)

Velazquez MA 2008 Assisted reproductive technologies in cattle: applications in livestock production, biomedical research and conservation biology. Annual Review of Biomedical Sciences 10 36-62. (https://doi.org/10.5016/1806-8774.2008.v10p36)

Velazquez MA, Smith CG, Smyth NR, Osmond C \& Fleming TP 2016 Advanced maternal age causes adverse programming of mouse blastocysts leading to altered growth and impaired cardiometabolic health in post-natal life. Human Reproduction 31 1970-1980. (https:// doi.org/10.1093/humrep/dew177)

Velazquez MA, Sheth B, Smith SJ, Eckert JJ, Osmond C \& Fleming TP 2018 Insulin and branched-chain amino acid depletion during mouse preimplantation embryo culture programmes body weight gain and raised blood pressure during early postnatal life. Biochimica et Biophysica Acta 1864 590-600. (https://doi.org/10.1016/j. bbadis.2017.11.020)

Wainstock T, Walfisch A, Shoham-Vardi I, Segal I, Harlev A, Sergienko R, Landau D \& Sheiner E 2017 Fertility treatments and pediatric neoplasms of the offspring: results of a population-based cohort with a median follow-up of 10 years. American Journal of Obstetrics and Gynecology $\mathbf{2 1 6}$ 314.e1-314.e14. (https://doi.org/10.1016/j.ajog.2017.01.015)

Wang X \& Proud CG 2009 Nutrient control of TORC1, a cellcycle regulator. Trends in Cell Biology 19 260-267. (https://doi. org/10.1016/j.tcb.2009.03.005)

Wang PX, Wang JJ, Lei YX, Xiao L \& Luo ZC 2012 Impact of fetal and infant exposure to the Chinese Great Famine on the risk of hypertension in adulthood. PLoS One 7 e49720. (https://doi. org/10.1371/journal.pone.0049720)

Wang H, Cheng Q, Li X, Hu F, Han L, Zhang H, Li L, Ge J, Ying X, Guo X, et al. 2018 Loss of TIGAR induces oxidative stress and meiotic defects in oocytes from obese mice. Molecular and Cellular Proteomics $\mathbf{1 7}$ 1354-1364. (https://doi.org/10.1074/mcp.RA118.000620)

Waterland RA, Kellermayer R, Laritsky E, Rayco-Solon P, Harris RA, Travisano M, Zhang W, Torskaya MS, Zhang J, Shen L, et al. 2010 Season of conception in rural gambia affects DNA methylation at putative human metastable epialleles. PLoS Genetics 6 e1001252. (https://doi.org/10.1371/journal.pgen.1001252)

Watkins AJ \& Sinclair KD 2014 Paternal low protein diet affects adult offspring cardiovascular and metabolic function in mice. American Journal of Physiology. Heart and Circulatory Physiology 306 H1444-H1452. (https://doi.org/10.1152/ajpheart.00981.2013)

Watkins AJ, Platt D, Papenbrock T, Wilkins A, Eckert JJ, Kwong WY, Osmond C, Hanson M \& Fleming TP 2007 Mouse embryo culture induces changes in postnatal phenotype including raised systolic blood pressure. PNAS 104 5449-5454. (https://doi.org/10.1073/ pnas.0610317104)

Watkins AJ, Ursell E, Panton R, Papenbrock T, Hollis L, Cunningham C, Wilkins A, Perry VH, Sheth B, Kwong WY, et al. 2008 Adaptive responses by mouse early embryos to maternal diet protect fetal growth but predispose to adult onset disease. Biology of Reproduction 78 299-306. (https://doi.org/10.1095/biolreprod.107.064220)

Watkins AJ, Lucas ES, Marfy-Smith S, Bates N, Kimber SJ \& Fleming TP 2015 Maternal nutrition modifies trophoblast giant cell phenotype and fetal growth in mice. Reproduction 149 563-575. (https://doi. org/10.1530/REP-14-0667)

Watkins AJ, Sirovica S, Stokes B, Isaacs M, Addison O \& Martin RA 2017 Paternal low protein diet programs preimplantation embryo gene expression, fetal growth and skeletal development in mice. Biochimica et Biophysica Acta 1863 1371-1381. (https://doi.org/10.1016/j. bbadis.2017.02.009)

Watkins AJ, Dias I, Tsuro H, Allen D, Emes RD, Moreton J, Wilson R, Ingram RJM \& Sinclair KD 2018 Paternal diet programs offspring health through sperm- and seminal plasma-specific pathways in mice. PNAS 115 10064-10069. (https://doi.org/10.1073/ pnas.1806333115)

Waynforth D 2018 Effects of conception using assisted reproductive technologies on infant health and development: an evolutionary perspective and analysis using UK millennium cohort data. Yale Journal of Biology and Medicine 91 225-235.

White CR, Denomme MM, Tekpetey FR, Feyles V, Power SGA \& Mann MRW 2015 High frequency of imprinted methylation errors in human preimplantation embryos. Scientific Reports 5 17311. (https:// doi.org/10.1038/srep17311)

White CR, MacDonald WA \& Mann MR 2016 Conservation of DNA methylation programming between mouse and human gametes and preimplantation embryos. Biology of Reproduction 95 61. (https://doi. org/10.1095/biolreprod.116.140319)

Whitelaw N, Bhattacharya S, Hoad G, Horgan GW, Hamilton M \& Haggarty P 2014 Epigenetic status in the offspring of spontaneous and assisted conception. Human Reproduction 29 1452-1458. (https:// doi.org/10.1093/humrep/deu094)

Williams CL, Teeling JL, Perry VH \& Fleming TP 2011 Mouse maternal systemic inflammation at the zygote stage causes blunted cytokine responsiveness in lipopolysaccharide-challenged adult offspring. BMC Biology 9 49. (https://doi.org/10.1186/1741-7007-9-49)

Williams CL, Bunch KJ, Murphy MFG, Stiller CA, Botting BJ, Wallace WH, Davies MC \& Sutcliffe AG 2018 Cancer risk in children born after donor ART. Human Reproduction 33 140-146. (https://doi.org/10.1093/ humrep/dex333)

Wyman A, Pinto AB, Sheridan R \& Moley KH 2008 One-cell zygote transfer from diabetic to nondiabetic mouse results in congenital https://joe.bioscientifica.com

https://doi.org/10.1530/JOE-18-0676
(C) 2019 Society for Endocrinology Published by Bioscientifica Ltd. Printed in Great Britain 
malformations and growth retardation in offspring. Endocrinology 149 466-469. (https://doi.org/10.1210/en.2007-1273)

Yang X, Wu LL, Chura LR, Liang X, Lane M, Norman RJ \& Robker RL 2012 Exposure to lipid-rich follicular fluid is associated with endoplasmic reticulum stress and impaired oocyte maturation in cumulus-oocyte complexes. Fertility and Sterility 97 1438-1443. (https://doi.org/10.1016/j.fertnstert.2012.02.034)

Zalensky A \& Zalenskaya I 2007 Organization of chromosomes in spermatozoa: an additional layer of epigenetic information? Biochemical Society Transactions 35 609-611. (https://doi.org/10.1042/ BST0350609)

Zandstra H, Brentjens LBPM, Spauwen B, Touwslager RNH, Bons JAP, Mulder AL, Smits LJM, van der Hoeven MAHBM, van Golde RJT, Evers JLH, et al. 2018 Association of culture medium with growth, weight and cardiovascular development of IVF children at the age of
9 years. Human Reproduction 33 1645-1656. (https://doi.org/10.1093/ humrep/dey246)

Zhao J, Zhai L, Liu Z, Wu S \& Xu L 2014 Leptin level and oxidative stress contribute to obesity-induced low testosterone in murine testicular tissue. Oxidative Medicine and Cellular Longevity 2014 190945. (https:// doi.org/10.1155/2014/190945)

Zhao J, Yan Y, Huang X \& Li Y 2018 Do the children born after assisted reproductive technology have an increased risk of birth defects? A systematic review and meta-analysis. Journal of Maternal-Fetal and Neonatal Medicine 1-12. (https://doi.org/10.1080/14767058.2018.14 88168)

Zimmet P, Shi Z, El-Osta A \& Ji L 2018 Epidemic T2DM, early development and epigenetics: implications of the Chinese Famine. Nature Reviews Endocrinology 14 738-746. (https://doi.org/10.1038/ s41574-018-0106-1)

Received in final form 21 January 2019

Accepted 1 February 2019

Accepted Preprint published online 1 February 2019 (c) 2019 Society for Endocrinology Published by Bioscientifica Ltd.
Printed in Great Britain 